\title{
MEMOIR
}

\section{STANLEY JACKSON ROWLAND}

S. J. Rowland, who died aged 74 on 6 July 1962 , at his delightful country home in Essex, hoped in his youth to become a surgeon but was destined to be an actuary. It may be that the profession has lost matter of interest, if not of value, by the absence of succinct and truthful accounts of the real reasons why some of its members adopted it. There is at least one case in which a youth, to whom his father mentioned the word 'actuary', learned that the parent did not know what the word meant.

At the Grocers' Company's School in north-cast London, Rowland was very good at mathematics and he entered the service of the 'Clerical, Medical' in 1904. Though he was never an employers' liability, he moved to the 'Equitable' in 1909 , thence to the 'Pearl' in 1917 and, 2 years later, to the 'Metropolitan Life' as Assistant Actuary. When that Office was absorbed by the 'London Life', he became a Joint Assistant Actuary and, then, as Secretary, its Second Officer. He retired in I950. Thus, he acquired a richly varied experience of life assurance under managers having marked and diverse gifts.

He won his Fellowship in 1914 and entered actively into the life of the Institute, serving on the Council for some 15 years and being a Vice-President from 1945 to 1948 . While he held this office, he and his wife took charge of the very happy 'overflow Dinner' set in Grocers' Hall in connexion with the Guildhall Banquet at the close of the Institute's Centenary Celebration.

For 7 years, Rowland served on the Board of Examiners and he crowned his work by being Chairman of the Appointments Board from 1949 until 1955.

In I9I3, while still an Associate, he contributed a Note to F.I.A. on the graduation of some Indian mortality figures. This was followed, in 1917 , by a Note, in which he was associated with W. P. Elderton, on graduation by Makeham's hypothesis. Twenty years later came a Paper, with F. H. Wales as joint author, on the taxation of an Annuity Fund. There was also a Note in 7.S.S., with no surgical connotation, on an approximate method of extracting roots.

Rowland was a member of the small band of young actuaries who, before the outbreak of the war of igi4, began to dine regularly at the 'Cheshire Cheese'. He passed in 1920, with the survivors, into the Gallio Club, of which he was Chairman for 1939-44. He had also the honour of membership of the Actuaries' Club.

He was a keen sportsman-cricketer, foothaller, lawn tennis and badminton player, fisherman and shot. Moreover, he took great delight in model engineering and made many things, including a large locomotive. He loved music and was interested especially in the organ.

Rowland had a quiet, salty and rcfreshing sense of humour exercised, onc remembers, with spontaneity and telling effect.

While living a full professional life and enjoying wide recreational activities, he did not forget other things. He was a devoted member of the Congregational Church and gave to it and its associated institutions advice without stint on matters within his special competence. After his retirement, he served for 6 years on the Saffron Walden Rural District Council. 
He was blessed by and in a happy domestic life; and his wife, his son and his daughter, in their bereavement, have the consolation of treasuring the memory of a true man.

In trying to realize their loss, Rowland's many friends will like to think of one who knew his own mind and who sought modestly to use his great powers in selfless service: this because he had a long-tried grasp of sound general principles, kept sure by his humbling himself under the mighty hand of God. His personal qualities, his career, his interests, his achievements and his friendships are unified in that context and made real in that light. This unifying reality, for those who can accept it, points forward. It was the triumphant, uncompromising kcynote of the Service in the Congregational Church of Bishop's Stortford at which he said 'Goodbye' to us-for him, 'no sadness of farewell: he saw his Pilot face to face'.

R. C. SIMMONDS 